Accepted manuscript of J. Mol. Struct. 1063 (2014) 83-91 http://dx.doi.org/10.1016/j.molstruc.2014.01.055

\title{
Functionalization of the benzobicyclo[3.2.1]octadiene skeleton via photocatalytic oxygenation of thiophene and furan derivatives: the impact of the type and position of the heteroatom
}

\author{
Dragana Vuk, ${ }^{\mathrm{a}}$ Ilijana Kikaš, ${ }^{\mathrm{a}}$ Krešimir Molčanov, ${ }^{\mathrm{c}}$ Ottó Horváth, ${ }^{* \mathrm{~b}}$ Irena Škorić ${ }^{* \mathrm{a}}$ \\ ${ }^{a}$ Department of Organic Chemistry, Faculty of Chemical Engineering and Technology, \\ University of Zagreb, 10000 Zagreb, Croatia \\ ${ }^{b}$ Department of General and Inorganic Chemistry, Institute of Chemistry, Faculty of \\ Engineering, University of Pannonia, P.O.B. 158, Veszprém H-8201, Hungary \\ iskoric@fkit.hr,otto@vegic.uni-pannon.hu \\ ${ }^{c}$ Department of Physical Chemistry, Rudjer Bošković Institute, Bijenička cesta 54, 10000 \\ Zagreb, Croatia
}

\begin{abstract}
Photocatalytic oxygenations of a furan and two thiophene derivatives of benzobicyclo[3.2.1]octadiene have been realized by using anionic and cationic manganese(III) porphyrins as catalysts. The replace of oxygen with sulfur in the heteroaromatic ring considerably decreased the reactivity of these heterocyclic compounds, probably due to the increased aromaticity. The end-products of the oxygenation of the thiophene derivatives significantly deviated from most of those formed from the corresponding furan compounds; the lower reactivity of the thiophene ring enhanced the role of the out-of-ring carbon atom in the reaction pathways. Besides, deviating from the behavior of the furan compounds, the types of the end-products formed from the corresponding thiophene derivatives did not depend on the charge of the photocatalyst, neither on the oxygen concentration. However, also in this case, the position of the heteroatom in the aromatic ring strongly affects the formation of the end-products.
\end{abstract}

Keywords: photocatalytic oxygenation, porphyrins, benzobicyclo[3.2.1]octadienes, thiophene derivative, furan derivative, heteroatom effect

\footnotetext{
* Corresponding authors. Tel.: +385-1-4597-241; fax: +385-1-4597-250 (I. Škorić), tel.: +36-88-624159; fax: +36-88-624-548 (O. Horváth).
} 


\section{Introduction}

Photocatalytic reactions play important roles in both natural and artificial systems such as photosynthesis ${ }^{1}$ and oxidative degradation of harmful organic pollutants in wastewater treatment. ${ }^{2,3}$ Connecting to the latter area, oxygenation of various organic compounds can also be achieved by photocatalysis in homogeneous systems, where the photocatalyst can generate very reactive oxygen-containing species such as singlet oxygen $\left({ }^{1} \mathrm{O}_{2}\right)$, hydroxyl radical $\left(\mathrm{HO}^{\bullet}\right)$, or superoxide radical $\left(\mathrm{O}_{2}{ }^{\bullet-}\right){ }^{4}$ Porphyrins proved to be successful in photocatalytic synthesis of several oxygenated derivatives of different types of organic compounds. While free-base porphyrins are well-known sensitizers for production of singlet oxygen, 5,6,7,8,9 metalloporphyrins are much more versatile photocatalysts due to their coordination ability promoting a wider range of oxidation reactions. They can be utilized in autooxidation reactions, hydroxylations or direct oxygen transfer yielding epoxides. ${ }^{10,11}$ Cationic manganese(III) porphyrins were applied as efficient catalysts for oxygenation of $\alpha$-pinene. Its selective epoxidation was achieved in aqueous systems at relatively low substrate:catalyst ratio $(\mathrm{S} / \mathrm{C}=500)$, while in aprotic organic solvents, such as benzene or toluene, allylic hydroxylation products were formed. ${ }^{12}$ Using various metalloporphyrins in acetonitrile, photocatalytic epoxidation of cyclooctene was also observed. ${ }^{13}$ Photocatalytic oxygenation of cycloalkenes $^{12,13,14}$ and other unsaturated heteroaromatics ${ }^{5}$ was achieved by application of both metalated and free-base porphyrins. $5,12,13,14$

These precedents inspired us to study the porphyrin-mediated photocatalytic oxygenation of 2,3-[3,2-b-furo]-6,7-benzobicyclo[3.2.1]octa-2,6-diene (1) (see in Fig. 1), ${ }^{15}$ the structure of which represents the basic skeleton of many biologically active and important substances isolated from nature. ${ }^{16,17,18}$

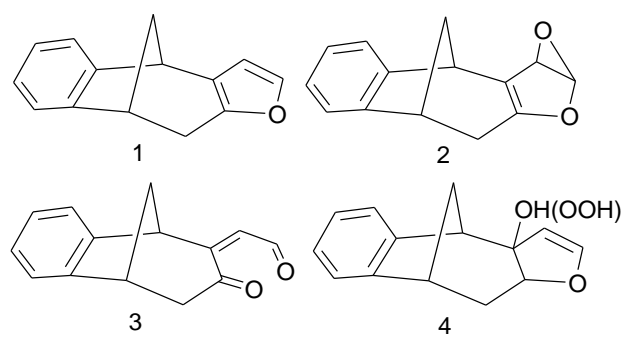

Fig. 1. Structures of the known furo-benzobicyclo[3.2.1] octadiene structure (1) and the photocatalytic oxygenation products of 1 (2-4). 
We have successfully realized the photocatalytic oxygenation of this special benzobicyclodiene containing fused furan ring by using the manganese(III) complexes of the cationic 5,10,15,20-tetrakis(1-methyl-4-pyridinium)porphyrin $\left(\mathrm{Mn}(\mathrm{III}) \mathrm{TMPyP}^{5+}\right)$ and the anionic $\quad 5,10,15,20$-tetrakis(4-sulfonatophenyl)porphyrin $\quad\left(\mathrm{Mn}(\mathrm{III}) \mathrm{TSPP}^{3-}\right){ }^{15} \quad$ In $\quad$ these photocatalytic oxygenation reactions, at pH 7 in air-saturated systems, new polycyclic epoxide (2) and furan ring-opened derivative (3) were obtained as characteristic products with the anionic manganese(III) complex, while hydroxy and hydroperoxy derivatives (4) were the main products by application of $\mathrm{Mn}(\mathrm{III}) \mathrm{TMPyP}^{5+}$ (Fig. 1). The deviating reaction pathways were interpreted in terms of steric and electronic effects. Our auxiliary experiments with the same substrate (1) indicated that application of the corresponding free-base porphyrins, generating singlet oxygen, led to the same end-product, independently of the charge of the catalyst. ${ }^{16}$ Besides, the photocatalytic oxygenation of the benzofuran analogue of $\mathbf{1}$ was also carried out; the steric hindrance (along with the electronic effect) led to the formation of only one type of product, no matter which porphyrin (anionic, cationic, free-base, or metalated) was used. ${ }^{16}$ These results with $\mathbf{1}$ and its benzofuran derivative served as useful pieces of information on the role of the structure and the reactivity of both the starting organic substrates and the photocatalysts from the viewpoints of oxygenation.

In order to gain more insight into the relations between the structure and the reactivity of the starting organic substrate, regarding its photocatalytic oxygenation by using both cationic and anionic manganese(III) porphyrins, we changed both the position and the type of the heteroatom in 1. Accordingly, in this work, 2,3-[2,3-b-furo]-6,7-benzobicyclo[3.2.1] octa-2,6diene (5), 2,3-[3,2-b-thieno]-6,7-benzobicyclo[3.2.1]octa-2,6-diene (6), and 2,3-[2,3-bthieno]-6,7-benzobicyclo[3.2.1] octa-2,6-diene (7) were studied under the same conditions as for 1 before. We anticipated that introduction of sulfur as heteroatom, by replacing the furan moiety with the thiophene, may have influence on the photocatalytic reaction mechanism, resulting in the formation of diverse photoproducts. Based solely on the aromaticity of heterocycles, ${ }^{17}$ the thiophene being more aromatic than furan, it might be expected that thiophene derivatives $\mathbf{6}$ and $\mathbf{7}$ will show different behavior in photocatalytic oxygenation than its parent furan derivatives $\mathbf{1}$ and $\mathbf{5}$.

The results of these examinations can serve as useful guiding for planning selective oxygenation of other benzobicyclo[3.2.1]octadiene derivatives in order to get new functionalized bicyclic skeleton found in many natural systems. ${ }^{18}$ 


\section{Experimental Section}

General. The ${ }^{1} \mathrm{H}$ spectra were recorded on a spectrometer at $600 \mathrm{MHz}$. The ${ }^{13} \mathrm{C}$ NMR spectra were registered at $150 \mathrm{MHz}$. All NMR spectra were measured in $\mathrm{CDCl}_{3}$ using tetramethylsilane as reference. The assignment of the signals is based on $2 \mathrm{D}-\mathrm{CH}$ correlation and 2D-HH-COSY experiments. UV spectra were measured on a UV/VIS Cary 50 spectrophotometer. IR spectra were recorded on a FTIR-ATR (film). Melting points were obtained using microscope equipped apparatus and are uncorrected. HRMS analysis were carried out on a mass spectrometer (MALDI TOF/TOF analyzer), equipped with Nd:YAG laser operating at $355 \mathrm{~nm}$ with firing rate $200 \mathrm{~Hz}$ in the positive $\left(\mathrm{H}^{+}\right)$or negative $\left(\mathrm{H}^{-}\right)$ion reflector mode. Silica gel (0.063-0.2 mm) was used for chromatographic purifications. Thinlayer chromatography (TLC) was performed silica gel $60 \mathrm{~F}_{254}$ plates. Solvents were purified by distillation.

\section{Typical experimental procedure for the photocatalytic oxygenation of 5 - 7}

A solution of $50 \mathrm{ml}$ of $\mathbf{5}-\mathbf{7}$ and the anionic or cationic manganese(III) porphyrins in acetone/water (50:50) was irradiated with a 70-W tungsten halogen immersion lamp (Philips, $\lambda_{\text {ir }}>380 \mathrm{~nm}$ ) in a thermostated $50-\mathrm{ml}$ cylindrical photoreactor. A stream of air or oxygen was passed through the solution at RT during $2 \mathrm{~h}$ (5, anionic Mn(III)porphyrin), 3h (5, cationic Mn(III)porphyrin), 16h (6, anionic and cationic Mn(III)porphyrin), 8h (7, anionic $\mathrm{Mn}$ (III)porphyrin) or (7, cationic Mn(III)porphyrin), also ensuring vigorous stirring. The following concentrations conditions were: $\mathrm{S} / \mathrm{C}=100$, porphyrin $=0.00111 \mathrm{mmol}$ and $\mathbf{5}-\mathbf{7}=$ $0.111 \mathrm{mmol}$. After termination of the photolysis acetone was removed by vacuum distillation. The remaining two phases were separated by standard methods. The water-insoluble oxygenation products remained in the organic phase. The photoproducts 8,9 (from 5 using anionic Mn(III)porphyrin), 10 (from 5 using cationic Mn(III)porphyrin) 11, 12, 13 (from 6 using anionic and cationic Mn(III)porphyrin) and 14 (from 7 using anionic and cationic Mn(III)porphyrin) (Schemes 1-3), were isolated by repeated thin-layer chromatography using dichloromethane /diethylether (9/1) as eluent and characterized by spectroscopic methods. 

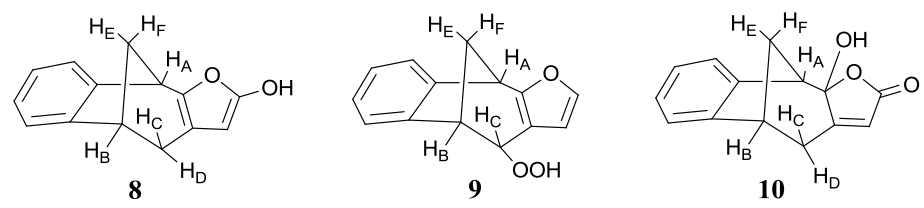

3-Oxatetracyclo[6.6.1.0 $\left.{ }^{2,6} .0^{9,14}\right]$ pentadeca-2(6),4,9(14),10,12-pentaen-4-ol (8): $24 \%$; $\mathrm{R}_{\mathrm{f}}$ 0.66 (dichloromethane /diethylether $=9: 1$ ); colourless crystals; mp 115-118 ${ }^{\circ} \mathrm{C}$; ${ }^{1} \mathrm{H}$ NMR $\left(\mathrm{CDCl}_{3}, 600 \mathrm{MHz}\right) \delta 7.20(\mathrm{~d}, J=7.3 \mathrm{~Hz}, 1 \mathrm{H}), 7.18-7.20(\mathrm{~m}, 3 \mathrm{H}), 5.33(\mathrm{~s},-\mathrm{OH}, 1 \mathrm{H}), 5.03(\mathrm{~d}$, $\left.J_{\mathrm{G},-\mathrm{OH}}=3.2 \mathrm{~Hz}, 1 \mathrm{H}\right), 3.68\left(\mathrm{t}, J=4.7 \mathrm{~Hz}, 1 \mathrm{H}, \mathrm{H}_{\mathrm{A}}\right), 3.46\left(\mathrm{dd}, J_{\mathrm{B}, \mathrm{E}}=7.2, J_{\mathrm{B}, \mathrm{C}}=2.9 \mathrm{~Hz}, 1 \mathrm{H}, \mathrm{H}_{\mathrm{B}}\right)$, $2.72-2.75\left(\mathrm{~m}, 2 \mathrm{H}, \mathrm{H}_{\mathrm{C}} / \mathrm{H}_{\mathrm{D}}\right), 2.53-2.47\left(\mathrm{~m}, 1 \mathrm{H}, \mathrm{H}_{\mathrm{E}}\right), 1.93\left(\mathrm{~d}, J_{\mathrm{E}, \mathrm{F}}=11.9 \mathrm{~Hz}, 1 \mathrm{H}, \mathrm{H}_{\mathrm{F}}\right) ;{ }^{13} \mathrm{C}$ NMR $\left(\mathrm{CDCl}_{3}, 150 \mathrm{MHz}\right) \delta 172.9$ (s), 167.8 (s), 144.8 (s), 139.7 (s), 127.9 (d), 127.4 (d), 125.0 (d), 122.6 (d), 118.0 (d), 83.0 (d), 46.5 (d), 41.8 (d), 40.8 (t), 35.4 (t); IR $v_{\max } / \mathrm{cm}^{-1}$ 2927, 2848, 2352, 1748, 1466, 1158, 1054, 892, 760; MS m/z $212\left(\mathrm{M}^{+}, 75 \%\right), 168$ (25\%), 115

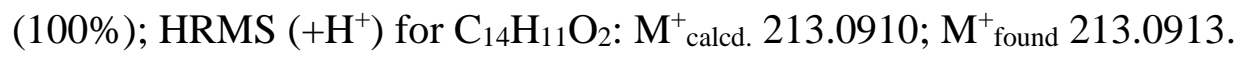

\section{7-Hydroperoxy-3-oxatetracyclo[6.6.1.0 $\left.{ }^{2,6} .0^{9,14}\right]$ pentadeca-2(6),4,9(14),10,12-pentaene (9):} $8 \%, \mathrm{R}_{\mathrm{f}} 0.48$ (dichloromethane /diethylether $=9: 1$ ); colourless crystals; $\mathrm{mp}>250{ }^{\circ} \mathrm{C} ;{ }^{1} \mathrm{H} \mathrm{NMR}$ $\left(\mathrm{CDCl}_{3}, 600 \mathrm{MHz}\right) \delta 7.43(\mathrm{t}, J=9.3 \mathrm{~Hz}, 1 \mathrm{H}), 7.35(\mathrm{dd}, J=7.3 ; 3.2 \mathrm{~Hz}, 1 \mathrm{H}), 7.30-7.20(\mathrm{~m}$, $3 \mathrm{H}), 6.83(\mathrm{dt}, J=7.4 ; 1.5 \mathrm{~Hz}, 1 \mathrm{H}), 6.50$ (s, 1H, -OOH), 6.45 (ddd, $J=12.0 ; 6.0 ; 1.9 \mathrm{~Hz}, 1 \mathrm{H})$, $5.94\left(\mathrm{~d}, J=5.7 \mathrm{~Hz}, 1 \mathrm{H}, \mathrm{H}_{\mathrm{C}}\right), 3.82-3.77\left(\mathrm{~m}, 1 \mathrm{H}, \mathrm{H}_{\mathrm{A}}\right), 2.92-2.96\left(\mathrm{~m}, 1 \mathrm{H}, \mathrm{H}_{\mathrm{B}}\right), 2.96(\mathrm{ddd}, J=$ 15.4; 5.7; $\left.1.0 \mathrm{~Hz}, 1 \mathrm{H}, \mathrm{H}_{\mathrm{F}}\right), 2.92$ - 2.96 (m, 1H, $\mathrm{H}_{\mathrm{E}}$ ); IR $v_{\max } / \mathrm{cm}^{-1} 3352,2912,1759,1460$, 1202, 1084, 1008, 924, 776; MS m/z $228\left(\mathrm{M}^{+}, 100 \%\right), 183$ (85\%), 153 (68\%), 115 (95\%); HRMS $\left(+\mathrm{H}^{+}\right)$for $\mathrm{C}_{14} \mathrm{H}_{12} \mathrm{O}_{3}: \mathrm{M}^{+}$calcd. $229.0860 ; \mathrm{M}^{+}$found 229.0852.

\section{2-Hydroxy-3-oxatetracyclo[6.6.1.0 $\left.{ }^{2,6} .0^{9,14}\right]$ pentadeca-5,9(14),10,12-tetraen-4-one}

$44 \% ; \mathrm{R}_{\mathrm{f}} 0.25$ (dichloromethane /diethylether $=9: 1$ ); colourless crystals; ${ }^{1} \mathrm{H} \mathrm{NMR}\left(\mathrm{CDCl}_{3}, 600\right.$ $\mathrm{MHz}) \delta 7.23(\mathrm{~d}, J=7.6 \mathrm{~Hz}, 1 \mathrm{H}), 7.18-7.09(\mathrm{~m}, 4 \mathrm{H}), 5.31\left(\mathrm{~d}, J=1.9 \mathrm{~Hz}, 1 \mathrm{H}, \mathrm{H}_{\mathrm{G}}\right), 3.60(\mathrm{~d}, J$ $\left.=4.8 \mathrm{~Hz}, 1 \mathrm{H}, \mathrm{H}_{\mathrm{A}}\right), 3.46\left(\mathrm{dd}, J_{\mathrm{B}, \mathrm{E}}=7.3, J_{\mathrm{B}, \mathrm{C}}=2.8 \mathrm{~Hz}, 1 \mathrm{H}, \mathrm{H}_{\mathrm{B}}\right), 3.32(\mathrm{~s}, 1 \mathrm{H},-\mathrm{OH}), 2.86(\mathrm{ddd}, J$ $\left.=13.6 ; 2.8 ; 1.0 \mathrm{~Hz}, 1 \mathrm{H}, \mathrm{H}_{\mathrm{C}} / \mathrm{H}_{\mathrm{D}}\right), 2.70\left(\mathrm{ddd}, J=13.6 ; 2.8 ; 1.0 \mathrm{~Hz}, 1 \mathrm{H}, \mathrm{H}_{\mathrm{C}} / \mathrm{H}_{\mathrm{D}}\right), 2.48\left(\mathrm{~d}, J_{\mathrm{E}, \mathrm{F}}=\right.$ $\left.11.7 \mathrm{~Hz}, 1 \mathrm{H}, \mathrm{H}_{\mathrm{F}}\right), 2.45-2.39\left(\mathrm{~m}, 1 \mathrm{H}, \mathrm{H}_{\mathrm{E}}\right) ;{ }^{13} \mathrm{C} \mathrm{NMR}\left(\mathrm{CDCl}_{3}, 150 \mathrm{MHz}\right) \delta 170.0(\mathrm{~s}), 166.8(\mathrm{~s})$, 145.2 (s), 140.6 (s), 128.2 (d), 127.5 (d), 124.9 (d), 122.9 (d), 119.0 (d), 105.2 (d), 50.8 (d), 41.9 (d), 40.6 (t), 34.1 (t); IR $v_{\max } / \mathrm{cm}^{-1}$ 2917, 2848, 1750, 1736, 1651, 1468, 1281, 1132, 1031, 936, 760; MS m/z $228\left(\mathrm{M}^{+}, 60 \%\right), 211$ (80\%), 155 (10\%), $116(100 \%)$; HRMS $\left(-\mathrm{H}^{+}\right)$for $\mathrm{C}_{14} \mathrm{H}_{14} \mathrm{O}_{3}: \mathrm{M}^{+}$calcd. 229.0860; $\mathrm{M}_{\text {found }}^{+} 229.0866$. 

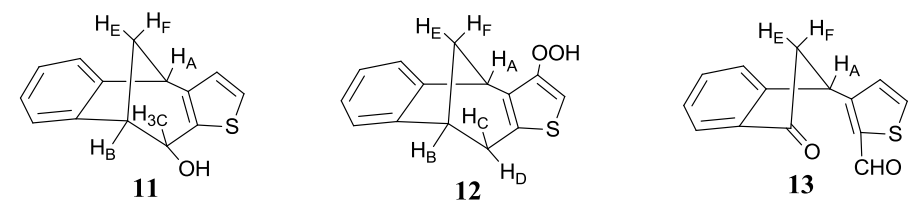

5-Thiatetracyclo[6.6.1.0 $\left.{ }^{2,6} .0^{9,14}\right]$ pentadeca-2(6),3,9(14),10,12-pentaen-7-ol (11): 15-23\% (depending on reaction conditions); $\mathrm{R}_{\mathrm{f}} 0.67$ (dichloromethane /diethylether = 9.5:0.5); colourless crystals; mp 123-125 ${ }^{\circ} \mathrm{C} ;{ }^{1} \mathrm{H}$ NMR $\delta\left(\mathrm{CDCl}_{3}, 600 \mathrm{MHz}\right) 7.36(\mathrm{~d}, J=7.0 \mathrm{~Hz}, 1 \mathrm{H})$, $7.15(\mathrm{~d}, J=7.0 \mathrm{~Hz}, 1 \mathrm{H}), 7.13(\mathrm{~d}, J=5.0 \mathrm{~Hz}, 1 \mathrm{H}), 7.08(\mathrm{dt}, J=7.0 ; 0.8 \mathrm{~Hz}, 1 \mathrm{H}), 7.04(\mathrm{dt}, J=$ 7.0; $0.8 \mathrm{~Hz}, 1 \mathrm{H}), 6.85(\mathrm{~d}, J=5.0 \mathrm{~Hz}, 1 \mathrm{H}), 4.78\left(\mathrm{dd}, J_{\mathrm{C},-\mathrm{OH}}=7.0 \mathrm{~Hz}, J_{\mathrm{B}, \mathrm{C}}=2.0 \mathrm{~Hz}, 1 \mathrm{H}, \mathrm{H}-\mathrm{C}\right)$, $4.04\left(\mathrm{~d}, J_{\mathrm{A}, \mathrm{E}}=4.1 \mathrm{~Hz}, 1 \mathrm{H}, \mathrm{H}-\mathrm{A}\right), 3.56-3.59(\mathrm{~m}, 1 \mathrm{H}, \mathrm{H}-\mathrm{B}), 2.44-2.48(\mathrm{~m}, 1 \mathrm{H}, \mathrm{H}-\mathrm{E}), 2.41(\mathrm{~d}$, $\left.J_{\mathrm{E}, \mathrm{F}}=10.7 \mathrm{~Hz}, 1 \mathrm{H}, \mathrm{H}-\mathrm{F}\right), 2.15\left(\mathrm{~d}, J_{\mathrm{C},-\mathrm{OH}}=7.0 \mathrm{~Hz}, 1 \mathrm{H},-\mathrm{OH}\right) ;{ }^{13} \mathrm{C} \mathrm{NMR}\left(\mathrm{CDCl}_{3}, 150 \mathrm{MHz}\right) \delta$ 159.5 (s), 151.5 (s), 144.8 (s), 141.8 (s), 126.2 (d), 125.8 (d), 124.5 (d), 124.2 (d), 124.1 (d), 121.2 (d), 68.7 (d, -OH), 48.8 (d), 42.5 (d), 38.5 (t); IR $v_{\max } / \mathrm{cm}^{-1} 3419$ (-OH), 2918, 1645, 1462, 1029, 752; MS m/z $228\left(\mathrm{M}^{+}, 100 \%\right), 211(60 \%)$; HRMS $\left(+\mathrm{Na}^{+}\right)$for $\mathrm{C}_{14} \mathrm{H}_{12} \mathrm{OS}: \mathrm{M}^{+}$calcd. $251.0502 ; \mathrm{M}^{+}$found 251.0513 .

\section{3-Hydroperoxy-5-thiatetracyclo $\left[6.6 .1 .0^{2,6} .0^{9,14}\right]$ pentadeca-2(6),3,9(14),10,12-pentaene}

(12): 5-36\% (depending on reaction conditions); $\mathrm{R}_{\mathrm{f}} 0.58$ (dichloromethane /diethylether $=$ 9.5:0.5); colourless crystals; mp 185-187 ${ }^{\circ} \mathrm{C} ;{ }^{1} \mathrm{H} \mathrm{NMR}\left(\mathrm{CDCl}_{3}, 600 \mathrm{MHz}\right) \delta 7.32$ (d, $J=7.5$ $\mathrm{Hz}, 1 \mathrm{H}), 7.22-7.28(\mathrm{~m}, 3 \mathrm{H}), 7.19(\mathrm{dt}, J=7.5 ; 1.0 \mathrm{~Hz}, 1 \mathrm{H}), 6.00(\mathrm{~s}, 1 \mathrm{H},-\mathrm{OOH}), 4.26\left(\mathrm{~d}, J_{\mathrm{A}, \mathrm{E}}\right.$ $=4.9 \mathrm{~Hz}, 1 \mathrm{H}, \mathrm{H}-\mathrm{A}), 3.38\left(\mathrm{dd}, J_{\mathrm{B}, \mathrm{E}}=7.1 \mathrm{~Hz}, J_{\mathrm{B}, \mathrm{C}}=3.2 \mathrm{~Hz}, 1 \mathrm{H}, \mathrm{H}-\mathrm{B}\right), 2.80-2.86(\mathrm{~m}, 1 \mathrm{H}, \mathrm{H}-$ E), $2.73-2.76(\mathrm{~m}, 2 \mathrm{H}, \mathrm{H}-\mathrm{C}, \mathrm{H}-\mathrm{D}), 2.08$ (d, $\left.J_{\mathrm{E}, \mathrm{F}}=10.8 \mathrm{~Hz}, 1 \mathrm{H}, \mathrm{H}-\mathrm{F}\right) ;{ }^{13} \mathrm{C} \mathrm{NMR}\left(\mathrm{CDCl}_{3}, 150\right.$ MHz) $\delta 173.0$ (s, -OOH), 146.5 (s), 142.6 (s), 135.4 (s), 135.3 (s), 128.2 (d), 127.5 (d), 123.8 (d) 123.6 (d), 122.9 (d), 49.4 (t), 46.1 (d), 45.5 (t), 39.7 (d); IR $v_{\max } / \mathrm{cm}^{-1} 3383(-\mathrm{OH}), 2926$, 1682, 1471, 1127, 1093, 979, 755; MS m/z 244 ( $\left.\mathrm{M}^{+}, 100 \%\right), 225$ (80\%), 214 (60\%); HRMS $\left(+\mathrm{H}^{+}\right)$for $\mathrm{C}_{14} \mathrm{H}_{12} \mathrm{O}_{2} \mathrm{~S}: \mathrm{M}^{+}$calcd. $245.0631 ; \mathrm{M}^{+}$found 245.0639 .

3-(3-Oxo-1-indanyl)-2-thenaldehyde (13): 4-35\% (depending on reaction conditions); $\mathrm{R}_{\mathrm{f}}$ 0.58 (dichloromethane /diethylether $=9.5 / 0.5$ ); colourless crystals; mp 143-145 ${ }^{\circ} \mathrm{C} ;{ }^{1} \mathrm{H}$ NMR $\left(\mathrm{CDCl}_{3}, 600 \mathrm{MHz}\right) \delta 10.13(\mathrm{~s}, 1 \mathrm{H},-\mathrm{CHO}), 7.85(\mathrm{~d}, J=7.7 \mathrm{~Hz}, 1 \mathrm{H}), 7.63(\mathrm{~d}, J=5.0 \mathrm{~Hz}, 1 \mathrm{H})$, $7.62(\mathrm{t}, J=7.7 \mathrm{~Hz}, 1 \mathrm{H}), 7.47(\mathrm{t}, J=7.7 \mathrm{~Hz}, 1 \mathrm{H}), 7.32(\mathrm{~d}, J=7.7 \mathrm{~Hz}, 1 \mathrm{H}), 6.71(\mathrm{~d}, J=5.0 \mathrm{~Hz}$, $1 \mathrm{H}), 5.43\left(\mathrm{dd}, J_{\mathrm{A}, \mathrm{E} / \mathrm{F}}=8.2 \mathrm{~Hz}, J_{\mathrm{A}, \mathrm{E} / \mathrm{F}}=3.7 \mathrm{~Hz}, 1 \mathrm{H}, \mathrm{H}-\mathrm{A}\right), 3.32\left(\mathrm{dd}, J_{\mathrm{E}, \mathrm{F}}=19.1 \mathrm{~Hz}, J_{\mathrm{A}, \mathrm{E} / \mathrm{F}}=8.2\right.$ $\mathrm{Hz}, 1 \mathrm{H}, \mathrm{H}-\mathrm{E} / \mathrm{H}-\mathrm{F}), 2.71\left(\mathrm{dd}, J_{\mathrm{E}, \mathrm{F}}=19.1 \mathrm{~Hz}, J_{\mathrm{A}, \mathrm{E} / \mathrm{F}}=3.7 \mathrm{~Hz}, 1 \mathrm{H}, \mathrm{H}-\mathrm{E} / \mathrm{H}-\mathrm{F}\right) ;{ }^{13} \mathrm{C} \mathrm{NMR}\left(\mathrm{CDCl}_{3}\right.$, 
$150 \mathrm{MHz}) \delta 204.5(\mathrm{~s},-\mathrm{C}=\mathrm{O}), 181.9(\mathrm{~d},-\mathrm{CHO}), 156.0(\mathrm{~s}), 151.6(\mathrm{~s}), 138.5(\mathrm{~s}), 136.5$ (s), 135.4 (d), 135.3 (d), 128.8 (d), 128.5 (d), 126.6 (d), 123.9 (d), 45.7 (t), 37.4 (d); IR $v_{\max } / \mathrm{cm}^{-1} 2928$, $1712(-\mathrm{C}=\mathrm{O}), 1663(-\mathrm{C}=\mathrm{O}), 1602,1431,1239,1093,758 ; \mathrm{MS} \mathrm{m} / z 242\left(\mathrm{M}^{+}, 100 \%\right), 225$ (20\%), $214(85 \%)$; HRMS $\left(+\mathrm{H}^{+}\right)$for $\mathrm{C}_{14} \mathrm{H}_{10} \mathrm{O}_{2} \mathrm{~S}: \mathrm{M}^{+}$calcd. $245.0631 ; \mathrm{M}^{+}$found 245.0633.

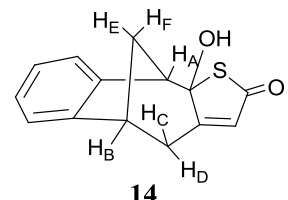

2-Hydroxy-3-thiatetracyclo[6.6.1.0 $\left.{ }^{2,6} \cdot 0^{9,14}\right]$ pentadeca-5,9(14),10,12-tetraen-4-one $60 \% ; \mathrm{R}_{\mathrm{f}} 0.39$ (dichloromethane /diethylether = 9.5:0.5); colourless crystals; mp 219-220 ${ }^{\circ} \mathrm{C}$; ${ }^{1} \mathrm{H} \mathrm{NMR}\left(\mathrm{CDCl}_{3}, 600 \mathrm{MHz}\right) \delta 7.26(\mathrm{dd}, J=7.3 ; 1.1 \mathrm{~Hz}, 1 \mathrm{H}), 7.15(\mathrm{dt}, J=7.3 ; 1.1 \mathrm{~Hz}, 1 \mathrm{H})$, $7.14(\mathrm{dd}, J=7.3 ; 1.1 \mathrm{~Hz}, 1 \mathrm{H}), 7.08(\mathrm{dt}, J=7.3 ; 1.1 \mathrm{~Hz}, 1 \mathrm{H}), 5.39$ (d, $\left.J_{\mathrm{D}, \mathrm{G}}=1.8 \mathrm{~Hz}, 1 \mathrm{H}, \mathrm{H}-\mathrm{G}\right)$, $3.37\left(\mathrm{~d}, J_{\mathrm{A}, \mathrm{E}}=4.8 \mathrm{~Hz}, 1 \mathrm{H}, \mathrm{H}-\mathrm{A}\right), 3.40\left(\mathrm{dd}, J_{\mathrm{B}, \mathrm{E}}=7.2 \mathrm{~Hz}, J_{\mathrm{B}, \mathrm{C}}=3.2 \mathrm{~Hz}, 1 \mathrm{H}, \mathrm{H}-\mathrm{B}\right), 2.96(\mathrm{dd}$, $\left.J_{\mathrm{C}, \mathrm{D}}=13,5 \mathrm{~Hz}, J_{\mathrm{D}, \mathrm{G}}=1.8 \mathrm{~Hz}, 1 \mathrm{H}, \mathrm{H}-\mathrm{D}\right), 2.73\left(\mathrm{dd}, J_{\mathrm{C}, \mathrm{D}}=13.5 \mathrm{~Hz}, J_{\mathrm{B}, \mathrm{C}}=3.2 \mathrm{~Hz}, 1 \mathrm{H}, \mathrm{H}-\mathrm{C}\right)$, $2.72(\mathrm{~s}, 1 \mathrm{H},-\mathrm{OH}), 2.70\left(\mathrm{~d}, J_{\mathrm{E}, \mathrm{F}}=11.6 \mathrm{~Hz}, 1 \mathrm{H}, \mathrm{H}-\mathrm{F}\right), 2.28-2.33(\mathrm{~m}, 1 \mathrm{H}, \mathrm{H}-\mathrm{E}) ;{ }^{13} \mathrm{C}$ NMR $\left(\mathrm{CDCl}_{3}, 150 \mathrm{MHz}\right) \delta 195.0(\mathrm{~s}), 171.0(\mathrm{~s}), 146.1(2 \mathrm{~s}), 140.9(\mathrm{~s}), 128.7$ (d), 128.1 (d), 126.7 (d), 125.6 (d), 122.7 (d), 52.3 (d), 41.5 (d), 39.5 (t), 35.2 (t); IR $v_{\max } / \mathrm{cm}^{-1}$ 2934, 1661 (-C=O), 1465, 1056, 760; MS m/z $228\left(\mathrm{M}^{+}-18,100 \%\right), 208$ (35\%), 115 (75\%); HRMS (+Na $\left.{ }^{+}\right)$for $\mathrm{C}_{14} \mathrm{H}_{12} \mathrm{O}_{2} \mathrm{~S}: \mathrm{M}^{+}$calcd. $267.0450 ; \mathrm{M}^{+}$found 267.0448 .

Supplementary crystallographic data for this paper can be obtained free of charge via www.ccdc.cam.ac.uk/conts/retrieving.html (or from the Cambridge Crystallographic Data Centre, 12, Union Road, Cambridge CB2 1EZ, UK; fax: +44 1223 336033; or deposit@ccdc.cam.ac.uk). CCDC-XXXX and XXXX contain the supplementary crystallographic data for this paper.

\section{Results and Discussion}

In our previous papers ${ }^{19,20}$ we have found that photochemical approach provides a simple and effective method to prepare 2,3- and 3,2-fused thiophene and furan polycyclic compounds $\mathbf{1},{ }^{20}$ 5-7, ${ }^{23}$ which can be interesting scaffolds for further diverse transformations, such as photocatalytic oxygenation reactions. ${ }^{15,16}$ In continuation of our interest in the effect of the heteroatom (its type ( $\mathrm{O}$ or $\mathrm{S}$ ) and position in the heteroaromatic ring) on these reactions, we 
have examined the polyheterocyclic compounds 5-7 in these respects.

Scheme 1 summarizes the products 8-10 of light-induced oxygenation of the furan derivative 5, using different porphyrins as photocatalysts. Schemes 2 and 3 present the reaction pathways for the photocatalytic oxygenation reactions of thiophene derivatives 6 (Scheme 2, giving products 11-13) and 7 (Scheme 3, giving only one product 14). Blank experiments were also carried out for all the three starting bicyclo structures 5-7. No permanent change was observed in the dark (after 3-hour stirring of oxygen-saturated solutions containing both substrate and anionic/cationic catalyst), neither upon irradiation in the absence of porphyrin. These observations clearly indicated that the substrate does not undergo any thermal reaction even in the presence of ground-state porphyrins.

Since under the experimental conditions applied (See Experimental Section) upon irradiation with polychromatic light $(\lambda>380 \mathrm{~nm})$ exclusively the porphyrin photocatalysts absorb in these systems (Fig. 2), the chemical changes observed can be unambiguously attributed to photoinduced reactions involving the excited-state of these macrocyclic compounds.

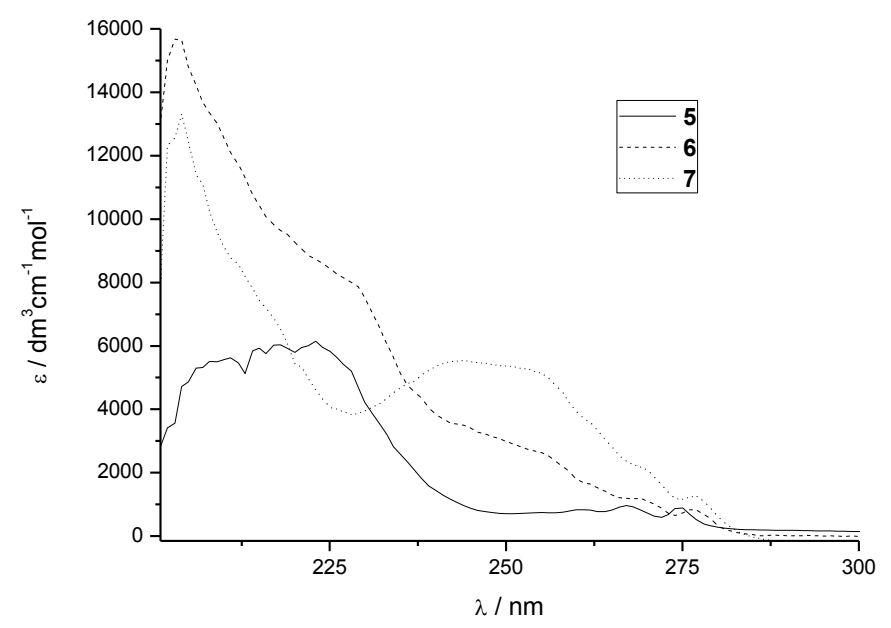

Fig. 2. Absorption spectra of the starting benzobicyclic structures 5-7 in 95\% ethanol.

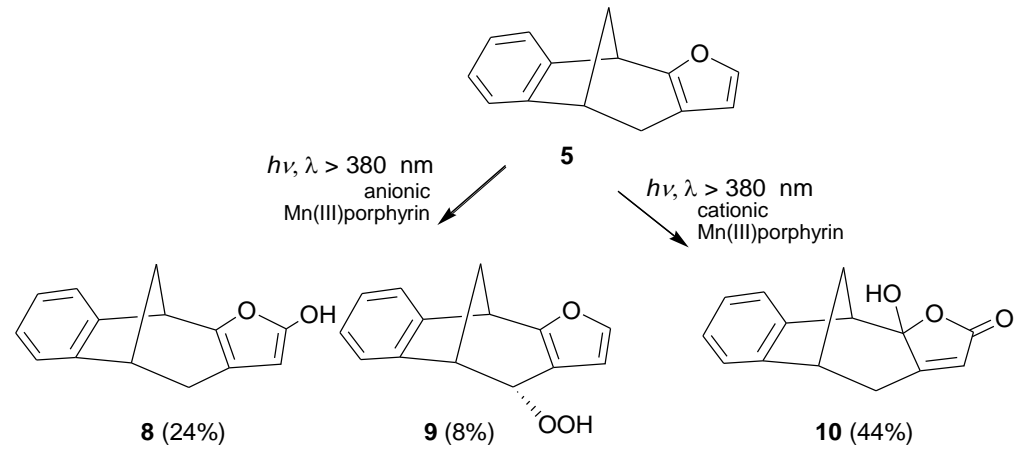


Scheme 1. Proposed reaction pathways for the photocatalytic oxygenation reactions of 5 ( $\mathrm{pH}=7$, oxygen-saturation).

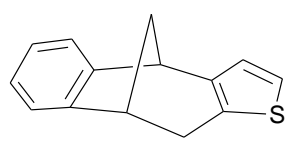

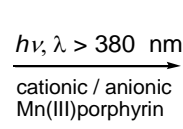

$\mathrm{Mn}(\mathrm{III})$ porphyrin

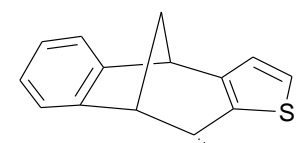

$11(15-23 \%) " \mathrm{OH}$

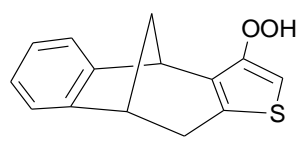

$12(5-36 \%)$

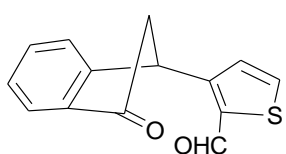

$13(4-35 \%)$

Scheme 2. Reaction pathway for the photocatalytic oxygenation reactions of $6(\mathrm{pH}=7$, oxygen-saturation).

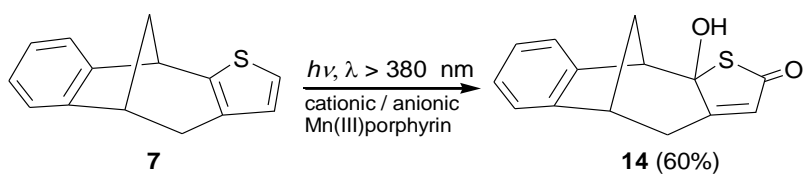

Scheme 3. Photocatalytic oxygenation of 7 to photoproduct 14 ( $\mathrm{pH}=7$, oxygen-saturation).

All the products 8-14 of the photocatalytic oxygenation reactions obtained from different heteroaromatic substrates 5-7 (Schemes 1-3), were isolated by repeated thin-layer chromatography and characterized by spectroscopic methods. From the NMR spectra, using different techniques $\left({ }^{1} \mathrm{H}\right.$ NMR, ${ }^{13} \mathrm{C}$ NMR, COSY and NOESY) and taking as a reference our previous results, ${ }^{15,16}$ structures of all compounds were determined and all protons and carbons were completely assigned. All the photoproducts have in the ${ }^{1} \mathrm{H}$ NMR spectra (Figs. 3 and 4) recognizable patterns but different number of signals in the aliphatic region, depending on the structure (See Experimental Section and Supp. Inf.). 


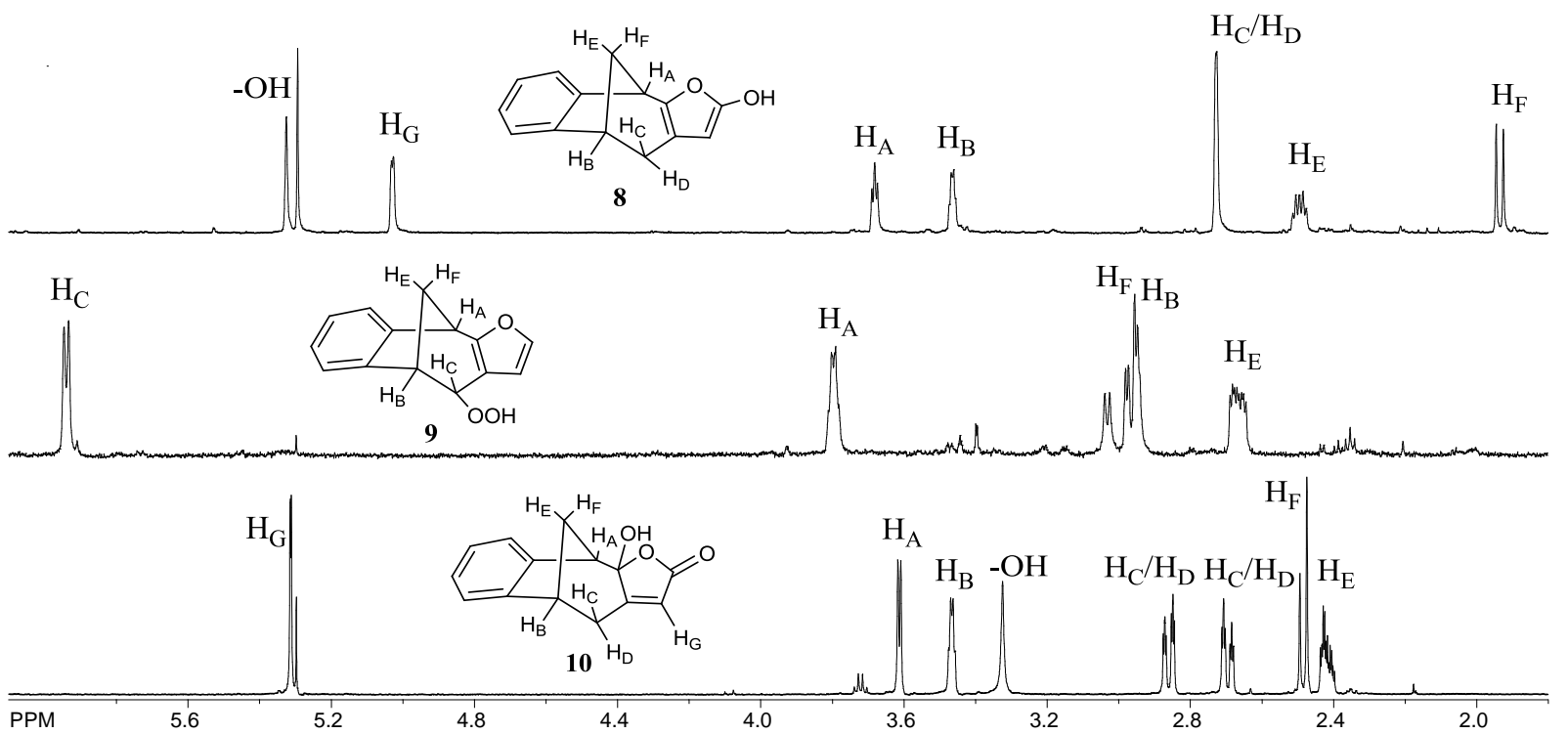

Fig. 3. Part of the ${ }^{1} \mathrm{H} \mathrm{NMR}\left(\mathrm{CDCl}_{3}, 600 \mathrm{MHz}\right)$ of photoproducts 8-10 obtained from furan derivative 5 .

These suggested results were confirmed by the ${ }^{13} \mathrm{C}$ NMR spectra, which unambiguously revealed the proposed structures with characteristic formyl, keto, hydroxy and/or hydroperoxy groups. The structures of 8-14 were obvious from the presence of well resolved and well recognizable six-proton-pattern (for products $\mathbf{8}, \mathbf{1 0}, \mathbf{1 2}$ and 14) between 2.0 and $4.3 \mathrm{ppm}$ with the characteristic couplings unmistakably pointed to this type of rigid benzobicyclic structures. The structure of these photoproducts was confirmed also by their ${ }^{13} \mathrm{C} \mathrm{NMR}$ spectra, which clearly revealed the proposed structure with 2 dublets and 2 triplets in the aliphatic region (See Experimental Section and Suppl. Inf) and the corresponding signals for keto or formyl groups. It can be seen the very well resolved five-proton-pattern (product 11), four-proton-pattern (compound 9) and three-proton-pattern (product 13) in the ${ }^{1} \mathrm{H}$ NMR spectra between 2.4 and $5.4 \mathrm{ppm}$ unmistakably points to the different structures of photooxygenation products. The endo-orientation of the hydroperoxy group (9) and hydroxyl group (11) is defined on the base of COSY and NOESY interactions (Figs. 5 and 6). 


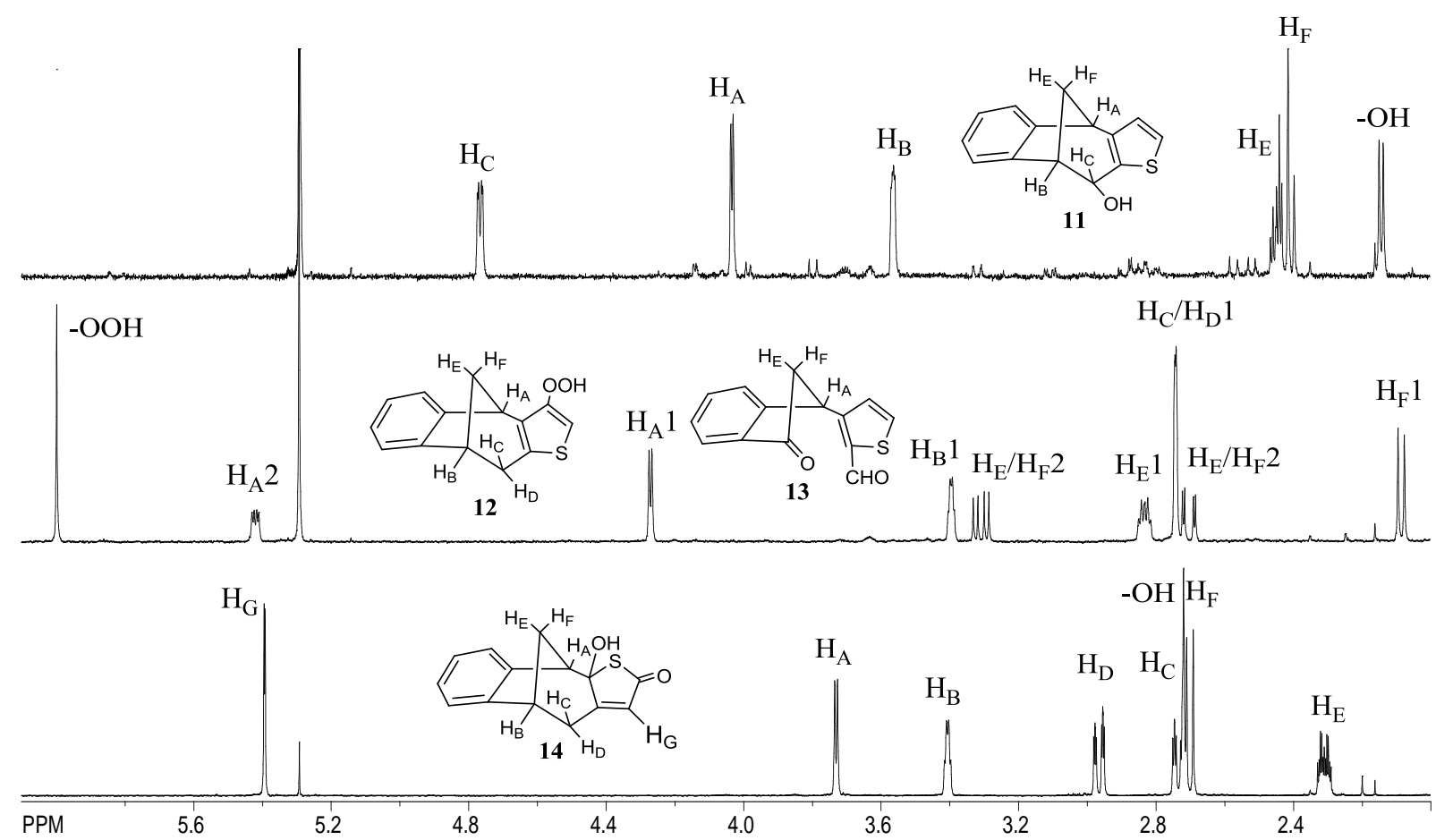

Fig. 4. Part of the ${ }^{1} \mathrm{H}$ NMR $\left(\mathrm{CDCl}_{3}, 600 \mathrm{MHz}\right)$ of photoproducts 11-13 (obtained from thiophene derivative 6) and compound 14 (obtained from 7).

Additionally, the MS spectra were very informative. Molecular ions $m / z, 212(8), m / z, 228$ (9, 10, 11) $\mathrm{m} / \mathrm{z} 244(\mathbf{1 2})$ and $\mathrm{m} / \mathrm{z} 242(\mathbf{1 3})$ indicated that one or two oxygen atoms are incorporated in the starting substrates 5, 6 or 7. IR spectra of 8-14 showed characteristic signals of the formyl, keto, hydroxy and/or hydroperoxy groups, further confirming the proposed photooxygenation products (See Suppl. Inf.). 


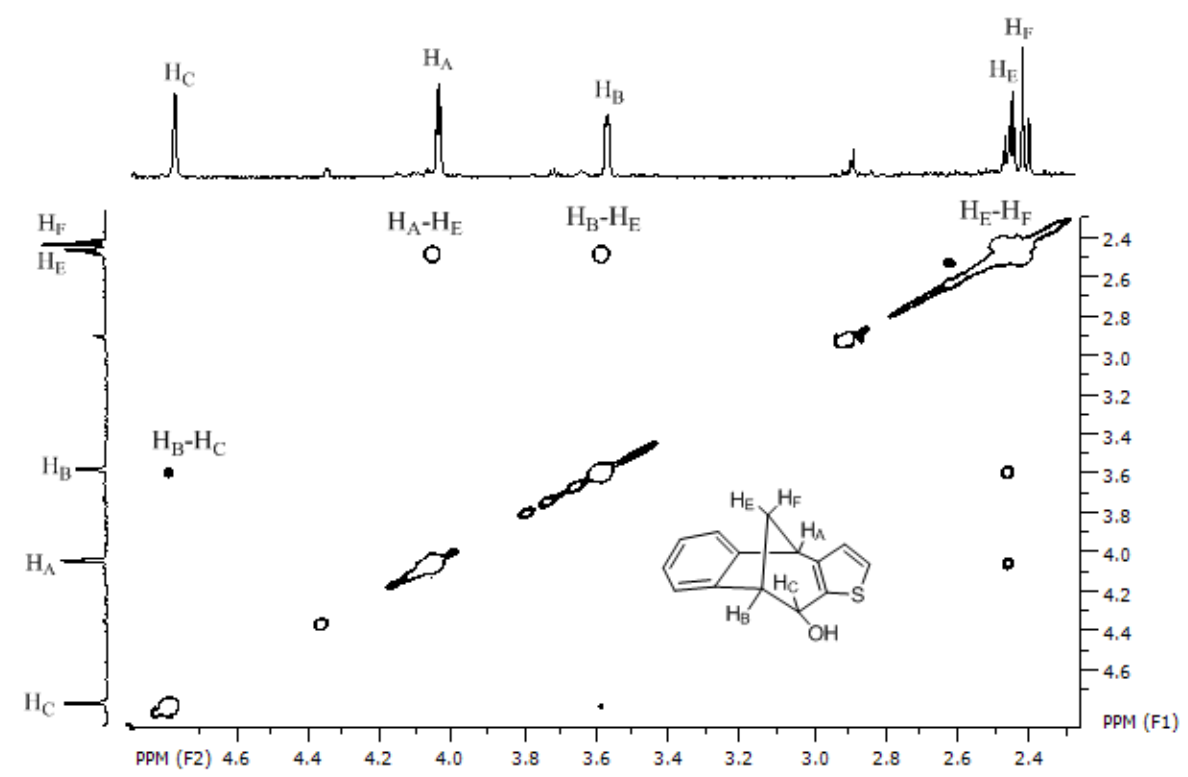

Fig. 5. Part of the COSY spectrum of the photoproduct 11.

Analogous compounds 10 and 14 (Fig 6) have almost identical molecular geometry (Fig. 7) due to the rigidity of the carbon skeleton. Therefore, phenyl and five-membered (thia)lactone rings are planar, with Cremer-Pople ${ }^{21}$ puckering parameter $\tau$ less than $5^{\circ}$. The five-membered ring C5-C6-C7-C10-C9 is in a boat conformation, with Cremer-Pople parameters $\mathrm{Q}$ being $0.435(4)$ and $0.435(2) \AA$ and $\varphi$ being 215.1(5) and 215.9(3) for $\mathbf{1 4}$ and 10, respectively. Sixmembered ring C3-C4-C5-C6-C7-C8 is a chair with puckering amplitude Q being 0.675(4) $\AA$ in 14 and 0.669(2) $\AA$ in 10. The seven-membered ring C3-C4-C5-C9-C10-C7-C8 is in both compounds a boat, with puckering amplitude of 1.296(3) and 1.267(2), respectively.

The crystals of both compounds are isostructural; unit cell of $\mathbf{1 4}$ is slightly larger (Table 2) due to the presence of sulfur atom. In both compounds, an intermolecular hydrogen bond $\mathrm{O} 2$ $\mathrm{H} 2 \mathrm{~A} \cdots \mathrm{O} 1^{i}$ [symmetry operator $\left.i\right)-1 / 2+x, 1 / 2-y,-1 / 2+z$ ] links the molecules into chains extending in the direction [101] (Fig. 7). The chains are linked by weaker $\mathrm{C}-\mathrm{H} \cdots \mathrm{O}$ hydrogen bonds into a 3D network (Table 1). 

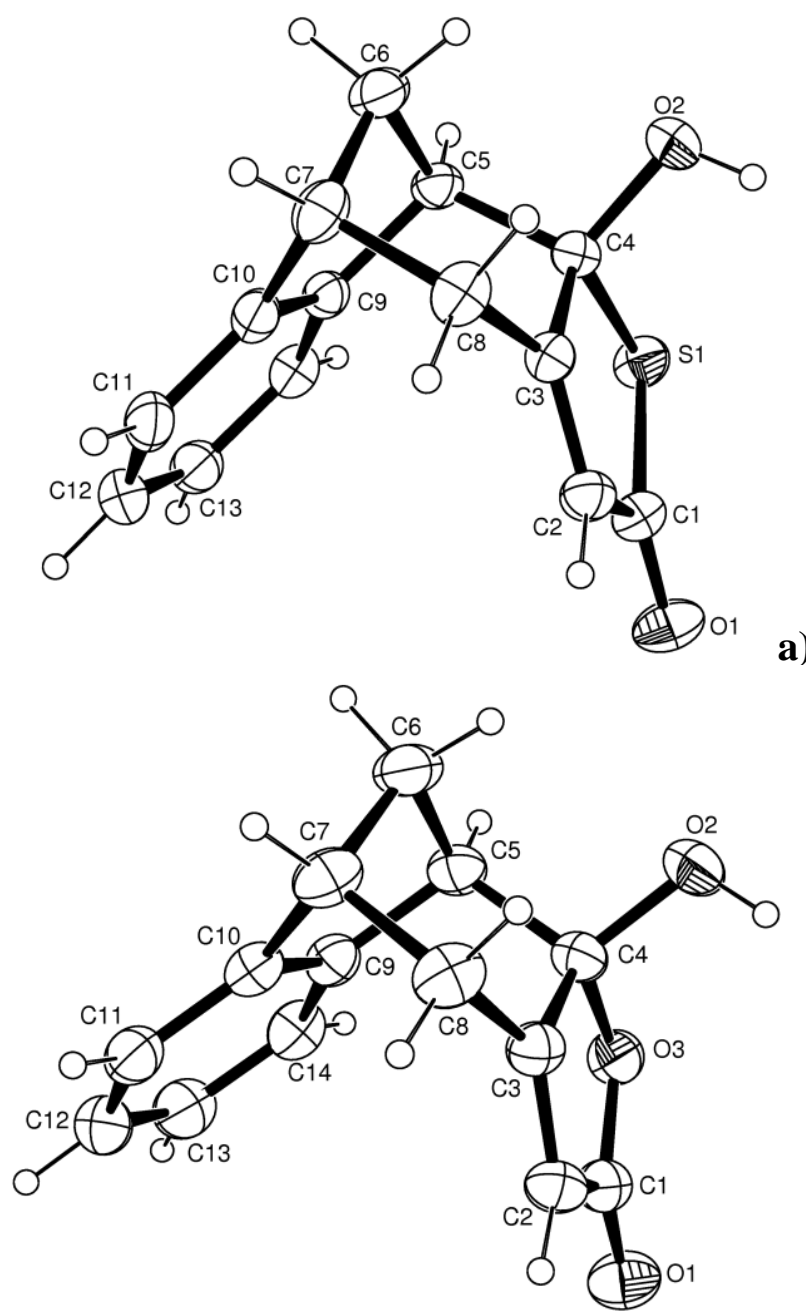

b)

Fig. 6. ORTEP-3 $3^{22}$ drawing of a) 14 and b) 10. Displacement ellipsoids are drawn for the probability of $30 \%$ and hydrogen atoms are shown as spheres of arbitrary radii.

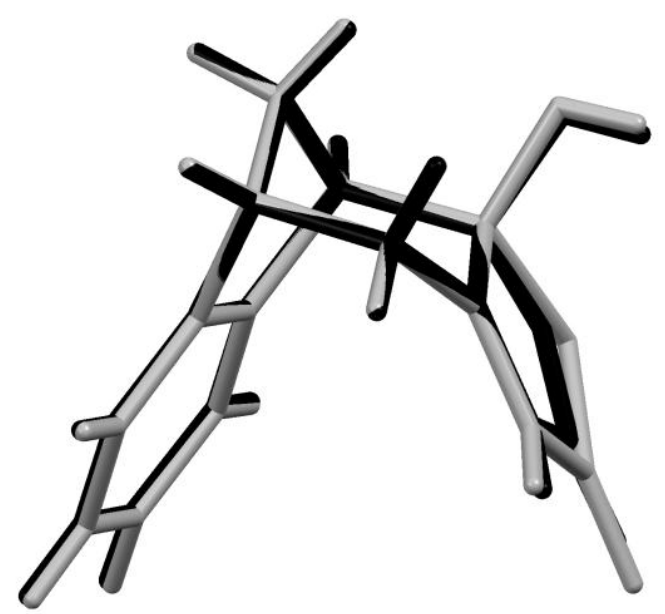

Fig. 7. Least-squares overlay of molecules $\mathbf{1 0}$ (black) and $\mathbf{1 4}$ (gray). 


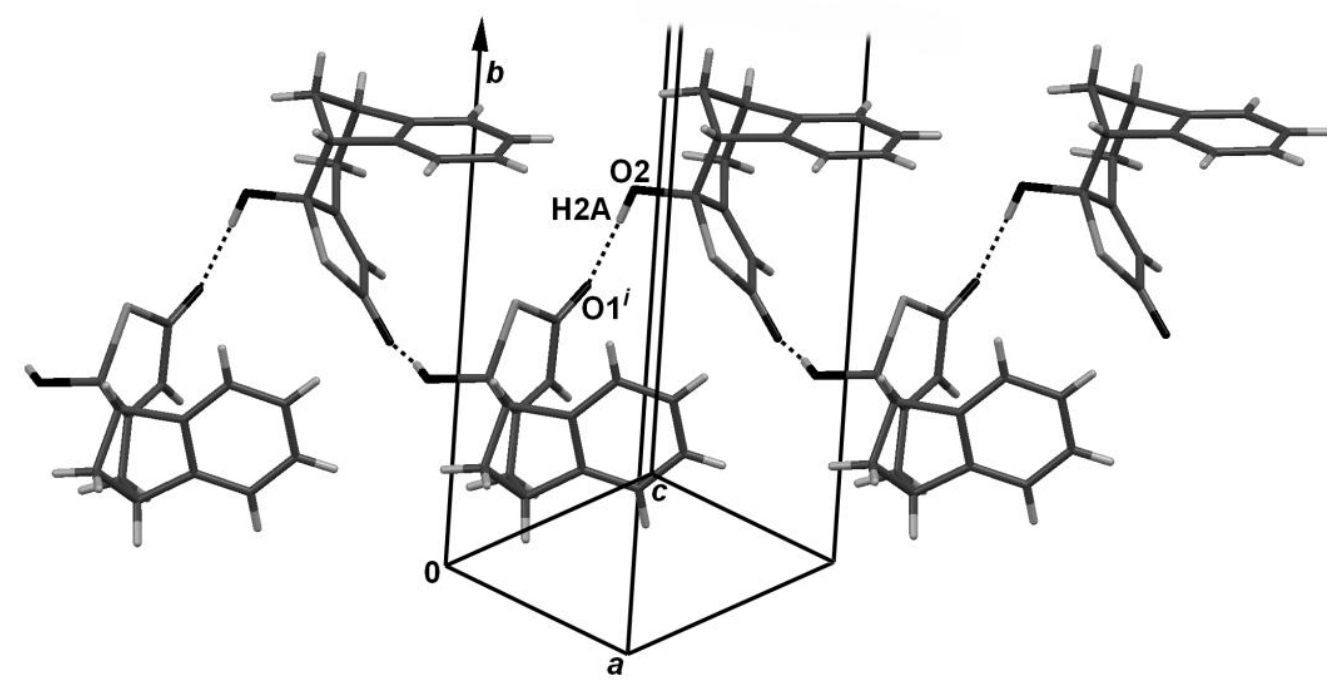

Fig, 8. Hydrogen bonded chains in crystal structure of $\mathbf{1 4}$. Symmetry operator: $i$ ) $-1 / 2+x, 1 / 2-$

$$
y,-1 / 2+z \text {. }
$$

Single crystal measurements were performed on an Oxford Diffraction Xcalibur Nova R (microfocus $\mathrm{Cu}$ tube) at room temperature [293(2) K]. Program package CrysAlis $\mathrm{PRO}^{23}$ was used for data reduction. The structure was solved using SHELXS97 ${ }^{24}$ and refined with SHELXL97. ${ }^{20}$ The models were refined using the full-matrix least squares refinement; all non-hydrogen atoms were refined anisotropically. Hydrogen atoms were modelled as riding entities using the AFIX command. Molecular geometry calculations were performed by PLATON,${ }^{25}$ and molecular graphics were prepared using ORTEP- $3,{ }^{26}$ and CCDC-Mercury. ${ }^{26}$ Crystallographic and refinement data for the structures reported in this paper are shown in Table 2.

Table 1. Geometric parameters of hydrogen bonds.

$$
D-\mathrm{H} / \AA \quad \mathrm{H} \cdots A / \AA \quad D \cdots A / \AA \quad D-\mathrm{H} \cdots A /^{\circ} \quad \text { Symm. op. on } A
$$

Compound 14

$\begin{array}{cccccc}\mathrm{O} 2-\mathrm{H} 2 \mathrm{~A} \cdots \mathrm{O} 1 & 0.82 & 1.94 & 2.759(4) & 173 & -1 / 2+x, 1 / 2-y,-1 / 2+z \\ \mathrm{C} 2-\mathrm{H} 2 \cdots \mathrm{O} 2 & 0.93 & 2.54 & 3.445(4) & 164 & 1+x, y, z \\ \mathrm{C} 13-\mathrm{H} 13 \cdots \mathrm{O} 2 & 0.93 & 2.59 & 3.346(5) & 139 & 1+x, y, z \\ \mathrm{C} 14-\mathrm{H} 14 \cdots \mathrm{O} 1 & 0.93 & 2.61 & 3.611(5) & 173 & -1 / 2+x, 1 / 2-y, 1 / 2+z\end{array}$




\begin{tabular}{cccccc}
\hline O2-H2A $\cdots \mathrm{O} 1$ & 0.82 & 1.94 & $2.706(2)$ & 155 & $-1 / 2+x, 1 / 2-y,-1 / 2+z$ \\
$\mathrm{C} 2-\mathrm{H} 2 \cdots \mathrm{O} 2$ & 0.93 & 2.48 & $3.339(2)$ & 153 & $1+x, y, z$ \\
$\mathrm{C} 13-\mathrm{H} 13 \cdots \mathrm{O} 2$ & 0.93 & 2.72 & $3.640(4)$ & 172 & $1+x, y, z$ \\
$\mathrm{C} 14-\mathrm{H} 14 \cdots \mathrm{O} 1$ & 0.93 & 2.94 & $3.769(5)$ & 150 & $-1 / 2+x, 1 / 2-y, 1 / 2+z$ \\
\hline
\end{tabular}

Table 2. Crystallographic, data collection and structure refinement details.

\begin{tabular}{|c|c|c|}
\hline Compound & 14 & 10 \\
\hline Empirical formula & $\mathrm{C}_{14} \mathrm{H}_{12} \mathrm{O}_{2} \mathrm{~S}$ & $\mathrm{C}_{14} \mathrm{H}_{12} \mathrm{O}_{3}$ \\
\hline $\begin{array}{l}\text { Formula wt. / } \mathrm{g} \mathrm{mol}^{-} \\
1\end{array}$ & 244.31 & 228.24 \\
\hline Crystal dimensions / & $0.25 \times 0.18 \times$ & $0.30 \times 0.18 \times$ \\
\hline $\mathrm{mm}$ & 0.12 & 0.10 \\
\hline Space group & $C c$ & $C c$ \\
\hline$a / \AA$ & $6.3924(2)$ & $6.6149(2)$ \\
\hline$b / \AA$ & $23.3676(6)$ & $22.9618(7)$ \\
\hline$c / \AA$ & $7.9709(2)$ & $7.6130(2)$ \\
\hline$\alpha /{ }^{\circ}$ & 90 & 90 \\
\hline$\beta /{ }^{\circ}$ & $102.006(3)$ & $101.217(3)$ \\
\hline$\gamma / \circ$ & 90 & 90 \\
\hline $\mathrm{Z}$ & 4 & 4 \\
\hline$V / \AA^{3}$ & 1164.61(6) & $1134.25(6)$ \\
\hline$D_{\text {calc }} / \mathrm{g} \mathrm{cm}^{-3}$ & 1.393 & 1.337 \\
\hline$\mu / \mathrm{mm}^{-1}$ & 2.351 & 0.768 \\
\hline$\Theta$ range $/^{\circ}$ & $3.78-75.54$ & $3.85-75.81$ \\
\hline$T / \mathrm{K}$ & 293(2) & 293(2) \\
\hline Radiation & 1.54179 & 1.54179 \\
\hline vawelength & $(\mathrm{Cu} K \alpha)$ & $(\mathrm{CuK \alpha})$ \\
\hline Diffractometer type & Xcalibur Nova & Xcalibur Nova \\
\hline Range of $h, k, l$ & $\begin{array}{l}-5<h<7 \\
-24<k<29 \\
-9<l<9\end{array}$ & $\begin{array}{l}-8<h<7 \\
-25<k<28 \\
-9<l<8\end{array}$ \\
\hline Reflections collected & 2358 & 2655 \\
\hline
\end{tabular}




\begin{tabular}{lll}
$\begin{array}{l}\text { Independent } \\
\text { reflections }\end{array}$ & 1410 & 1474 \\
$\begin{array}{l}\text { Observed reflections } \\
(I \geq 2 \sigma)\end{array}$ & 1385 & 1423 \\
Absorption & Multi-scan & Multi-scan \\
correction & & \\
$R_{\text {int }}$ & 0.0272 & 0.0215 \\
$R(F)$ & 0.0445 & 0.0293 \\
$R_{w}\left(F^{2}\right)$ & 0.1196 & 0.0826 \\
Goodness of fit & 1.036 & 1.082 \\
$\mathrm{H}$ atom treatment & Constrained & Constrained \\
No. of parameters & 152 & 155 \\
No. of restraints & 2 & 2 \\
$\Delta \rho_{\max }, \Delta \rho_{\text {min }}\left(\mathrm{e} \AA^{-3}\right)$ & $0.394 ;-0.271$ & $0.126 ;-0.119$ \\
\hline
\end{tabular}

According to earlier works ${ }^{12}$ and more recent studies, ${ }^{13,27,28}$ in the case of manganese(III) porphyrins as photocatalysts, $(\mathrm{P}) \mathrm{Mn}^{\mathrm{IV}}=\mathrm{O}$ and $(\mathrm{P}) \mathrm{Mn}^{\mathrm{V}}=\mathrm{O}$ intermediates played the key role of the in situ generated reactive species in the oxygenation of cycloalkenes. $(\mathrm{P}) \mathrm{Mn}^{\mathrm{IV}}=\mathrm{O}$ can be produced by a photoinduced homolysis of the metal-ligand bond with chloride or hydroxide axial ligands in aqueous systems. ${ }^{11,12}$ In the latter case the $\mathrm{Mn}(\mathrm{II})$ species formed in the primary photochemical step (Eq. 1) undergoes an oxidation with the dissolved $\mathrm{O}_{2}$ (Eq. 2).

$(\mathrm{P}) \mathrm{Mn}^{\mathrm{III}} \mathrm{OH}+h v \rightarrow(\mathrm{P}) \mathrm{Mn}^{\mathrm{II}}+{ }^{\bullet} \mathrm{OH}$

$2(\mathrm{P}) \mathrm{Mn}^{\mathrm{II}}+\mathrm{O}_{2} \rightarrow 2(\mathrm{P}) \mathrm{Mn}^{\mathrm{IV}}=\mathrm{O}$

Eq. 2 represents an overall reaction comprising several steps. ${ }^{11}$ Our experiments were carried out in water-acetone solvent mixture, thus hydroxide or water was axially coordinated to the $\mathrm{Mn}$ (III) center. Hence, hydroxyl radicals generated in the primary photochemical step most probably react with the organic solvent. Disproportionation of the $\mathrm{Mn}$ (IV) complexes formed produces highly reactive manganese(V)-oxo species (Eq. 3). ${ }^{27,28}$

$2(\mathrm{P}) \mathrm{Mn}^{\mathrm{IV}}=\mathrm{O}+\mathrm{H}^{+} \rightleftharpoons(\mathrm{P}) \mathrm{Mn}^{\mathrm{V}}=\mathrm{O}+(\mathrm{P}) \mathrm{Mn}^{\mathrm{III}} \mathrm{OH}$

Disproportionation is significantly faster than synproportionation in this equilibrium system, 
besides, a polar solvent promotes the previous process, thus it occurs with nearly a diffusioncontrolled rate constant. ${ }^{27}$ Further, the rate constants for epoxidation of olefins are several orders of magnitude higher for manganese(V)-oxo porphyrins than for the corresponding $\mathrm{Mn}(\mathrm{IV})$ species. Accordingly, $(\mathrm{P}) \mathrm{Mn}^{\mathrm{V}}=\mathrm{O}$ can be considered as the major oxidant in the photocatalytic oxygenations in our systems.

The end-products of photocatalytic oxygenation of 5 indicate (Scheme 1) strongly deviate from those obtained with the other furyl isomer (1) under the same experimental conditions. ${ }^{15,16}$ These results confirm our expectations that the position of the heteroatom (O) strongly influences the reactivity of the substrate toward both photocatalysts. While in the case of 1, using the anionic $\mathrm{Mn}(\mathrm{III})$ porphyrin, epoxide (2) and furan ring-opened (3) derivatives were the main products, photocatalytic oxygenation of $\mathbf{5}$ led to the formation of hydroxy (8) and hydroperoxy (9) derivatives (in the ratio of 3:1). Notably, after 30 min irradiation, predominantly the corresponding epoxide was determined as the main intermediate (55-60\%) in the reaction (Scheme 1), but after 2 hours irradiation only traces of this species were detected using NMR spectroscopy. This observation clearly indicates that this epoxide is the precursor of the hydroxy (8) derivative, while the other end-product $(\mathbf{9})$ is formed in another reaction pathway. Although this product is the minor one, it should be emphasized that functionalization on this carbon atom could not occur with the other furyl isomer (1) under any of the conditions applied. ${ }^{15,16}$ These results suggest that the more distant position of the heteroatom $(\mathrm{O})$ from this carbon atom significantly increases the (nucleophilic) reactivity of the latter one. Besides, it considerably promotes the hydroxylation of the neighboring carbon atom (through an epoxide intermediate), which could not be observed for 1 at all.

What is more striking, in the presence of the cationic $\mathrm{Mn}$ (III) porphyrin only one end-product was formed (Scheme 1), a hydroxybutenolide derivative (10), which is similar to that observed in the photocatalytic oxygenation of $\mathbf{1}$, although by using the anionic free base in that case, where photochemically generated singlet oxygen was the oxidative agent, the attack of which was not sterically hindered at the carbon atoms next to the heteroatom $(\mathrm{O}) .{ }^{15}$ The results in the present study suggest that in isomer 5 the inner double bond is more preferred by the attack of the cationic Mn(III) porphyrin than by the anionic one. It is in accordance with our general observations in the photocatalytic oxygenation of $\mathbf{1},{ }^{15}$ and also with the formation of 9 with the anionic photocatalyst because the positive charge increases the electrophilic reactivity of the catalyst, thus it promotes its attack even at the sterically less favorable inner double bond. 
The replace of the heteroatom $\mathrm{O}$ in $\mathbf{1}$ with $\mathrm{S}(\mathbf{6})$ resulted in a significant change in the product types of the photocatalytic oxygenation. Deviating from the case of $\mathbf{1}$, the end-products of the oxygenation of 6 did not depend on the charge of the Mn(III) porphyrin. Besides, not only the types but also the ratios of theindividual products were practically catalyst-independent in oxygen-saturated systems (see the data of Table 3 ).

Table 3. End-products with yields (\%) obtained in the photocatalytic oxygenation of $\mathbf{6}$, using anionic and cationic $\mathrm{Mn}(\mathrm{III})$ porphyrins as catalysts at $\mathrm{pH}=7$.

\begin{tabular}{|cccc|}
\hline Condition/Compound & $\mathbf{1 1}$ & $\mathbf{1 2}$ & $\mathbf{1 3}$ \\
\hline$\%$ (anionic Mn(III) porphyrin, \\
$\begin{array}{c}\text { oxygen-saturation) } \\
\% \text { (cationic Mn(III) porphyrin, } \\
\text { oxygen-saturation) }\end{array}$ & 23 & 36 & 8 \\
$\%$ (cationic Mn(III) porphyrin, \\
air-saturation)
\end{tabular}

These results suggest that the different electrophilic characters of the photocatalysts do not play a determining role in the mechanism of the reactions in these systems. This phenomenon may be related to the fact that the reactivity of the thiophene derivative (6) was much lower than that of the corresponding furan analogue (1); while for the latter one 2 hours irradiation was enough for the total conversion in oxygen- or air-saturated systems, the previous one needed at least 16 hours under the same conditions. (Moreover, in the case of air-saturated system with anionic $\mathrm{Mn}(\mathrm{III})$ porphyrin, 16 hours irradiation was not enough for the total conversion, thus no yields could be given in Table 1 for this condition.) This may be attributed to the much higher aromaticity of the thiophene ring stabilizing the heterocycle.

As to the types of the products, none of their analogues was obtained in the case of $\mathbf{1},{ }^{15,16}$ confirming the dramatic change in the electronic structure by replacement of $\mathrm{O}$ with $\mathrm{S}$. The products formed from 6 suggest that the attack by hydroxyl radicals (Eq 1) may play a more determining role in this system than that by the $\mathrm{Mn}(\mathrm{V})=\mathrm{O}$ species, also in accordance with the catalyst-independent yields. The relatively high stability of the thiophene ring may resulted in 
the formation of only one ring-substituted (hydroperoxy) derivative (12), while the other two products are the result of the electrophilic attack at the out-of-ring carbon atom. Further oxidation of hydroxy derivative $\mathbf{1 1}$ can lead to the allylic hydroperoxy derivative (Scheme 4) which can be involved in further hydrolysis to the dicarbonated compound $\mathbf{1 3}$ via bondcleavage in the last step of the proposed Hock fragmentation. ${ }^{29}$ This route is confirmed by the data of yields in oxygen-saturated systems. Interestingly, in air-saturated system with cationic Mn(III) porphyrin the hydroperoxy derivative (12) has the lowest yield, while the bondbroken keto-formyl derivative (13) the highest. This data suggest that the efficient reaction with relatively stable thiophene ring needs higher oxygen concentration. Unexpectedly, the transformation (oxidation) of $\mathbf{1 1}$ to $\mathbf{1 3}$ was more effective in air- than in oxygen-saturated system.

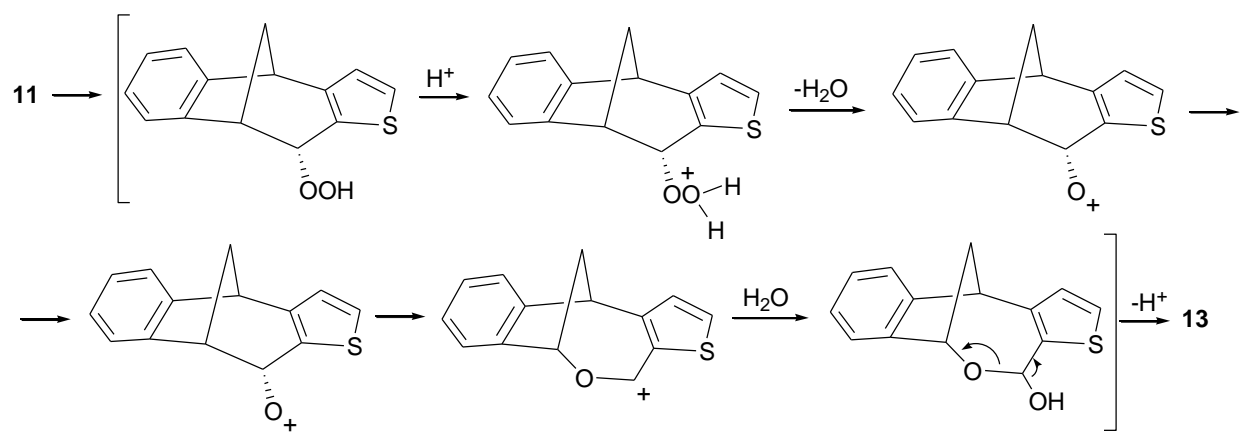

Scheme 4. Hock fragmentation to dicarbonylated photoproduct 13.

Similarly to the thiophene derivative $\mathbf{6}$, the end-products of the photocatalytic oxygenation of the other isomer (7) did not depend either on the charge of the Mn(III) porphyrin photocatalyst. However, in this case only one characteristic end-product (14) was detected (with about the same yield in both air- and oxygen-saturated systems.

The structure of this compound fully agrees with that of $\mathbf{1 0}$, the end-product of the photocatalytic oxygenation of the corresponding furan derivative (5) obtained by application of the cationic $\mathrm{Mn}$ (III) porphyrin. This result indicates that, unexpectedly, although the thiophene derivatives are less reactive than the corresponding furan compounds, in the case of the isomer 7 even the inner double bond could be successfully attacked by not only the cationic but also the anionic $\mathrm{Mn}(\mathrm{V})$ species. This phenomenon may be interpreted by the electron-donating effect of the bicyclic moiety connecting to the inner carbon atom next to the heteroatom (S). This effect may increase the nucleophilic reactivity of this carbon atom involved in the aromatic system. 


\section{Conclusions}

In this study we have clearly demonstrated that the type of the heteroatom and its position in the heteroaromatic ring significantly affect the behavior of these polyheterocyclic compounds in photocatalytic oxygenation processes. Compared to the furan derivatives, the corresponding thiophene isomers displayed much lower reactivity, probably due to the considerably higher aromaticity of the thiophene ring stabilizing the heterocycle. Nevertheless, after longer periods of irradiation the latter compounds also underwent oxygenation reactions leading to various end-products, which, however, deviating from the case of the furan derivatives, did not depend on the charge of the photocatalyst. Moreover, in the case of $\mathbf{6}$, two end-products of three were formed via reaction of the carbon atom out of the heterocycle, which did not occur in the oxygenation of the corresponding furan derivative (1) at all. Interestingly, however, the structure of the only end-product from the other thiophene derivative (7) fully agreed with that of the one obtained from the corresponding furan isomer (5) by application of cationic $\mathrm{Mn}$ (III) porphyrin. In the continuation of this work we would like to improve the selectivity of the systems giving several end-products, e.g. by examination of the effects of $\mathrm{pH}$.

This type of photocatalytic oxygenation can also be applied for further reactions of these products which may lead to interesting water-soluble compounds via thermal transformations such as addition or substitution. The obtained results can be utilized in functionalization of similar types of heteropolycyclic compounds for preparation of molecules of various bioactivity and can serve as useful guidance for planning selective oxygenation of other benzobicyclo[3.2.1] octadiene derivatives in order to get new functionalized bicyclic skeleton found in many natural systems. ${ }^{16}$

\section{Acknowledgment}

The financial supports by the Croatian Ministry of Science, Education and Sports (1250982933-2926, and 098-1191344-2943), the Hungarian Scientific Research Fund (OTKA, NN107310), the Hungarian Government and the European Union (TÁMOP-4.2.2.A11/1/KONV-2012-0071) are gratefully acknowledged. 


\section{Notes and references}

$\dagger$ Electronic Supplementary Information (ESI) available: ${ }^{1} \mathrm{H},{ }^{13} \mathrm{C}$, IR and MS spectra of all new compounds.

${ }^{1}$ L. R. Milgrom, The Colours of Life: An Introduction to the Chemistry of Porphyrins and Related Compounds, Oxford University Press, Oxford, 1997, 15 and 101.

${ }^{2}$ O. T. Woo, W. K. Chung, K. H. Wong, A. T. Chow, P. K. Wong, J. Hazard. Mater. 168 (2009) 1192.

${ }^{3}$ E. Szabó-Bárdos, O. Markovics, O. Horváth, N. Törő, G. Kiss, Water Res. 45 (2011) 1617.

${ }^{4}$ P. Boule, D. Bahnemann, P. Robertson (editors), In Environmental Photochemistry Part II (The Handbook of Environmental Chemistry / Reactions and Processes), C. Richard, S. Canonica, Aquatic Phototransformation of Organic Contaminants Induced by Coloured Dissolved Natural Organic Matter, Springer, Berlin, 2005, 299.

${ }^{5}$ K. Gollnick, A. Griesbeck, Tetrahedron 41 (1985) 2057.

${ }^{6}$ N. J. Turro, Modern Molecular Photochemistry, University Science Books, Sausalito, 1991, 587.

${ }^{7}$ M. R. Iesce, F. Cermola, A. Guitto, R. Scarpati, M. L. Graziano, J. Org. Chem. 60 (1995) 5324.

${ }^{8}$ C. J. P. Monteiro, M. M. Pereira, M. E. Azenha, H. D. Burrows, C. Serpa, L. G. Arnaut, M. J. Tapia, M. Sarakha, P. Wong-Wah-Chung, S. Navaratnam, Photochem. Photobiol. Sci. 4 (2005) 617.

${ }^{9}$ T. Montagnon, M. Tofi, G. Vissilikogiannakis, Acc. Chem. Res. 41 (2008) 1001.

${ }^{10}$ L. Weber, R. Hommel, G. Haufe, J. Behling, H. Hennig, J. Am. Chem. Soc. 116 (1994) 2400.

${ }^{11}$ H. Hennig, J. Behling, R. Meusinger, L. Weber, Chem. Ber. 128 (1995) 229.

${ }^{12}$ H. Hennig, Coord. Chem. Rev. 182 (1999) 101 and references therein.

${ }^{13}$ M. Hajimohammadi, F. Bahadoran, S. S. H. Davarani, N. Safari, Reac. Kinet. Mech. Cat. 99 (2010) 243.

${ }^{14}$ A. Maldotti, L. Andreotti, A. Molinari, G. Varani, G. Cerichelli, M. Chiarini, Green Chem. 3 (2001) 42.

${ }^{15}$ I. Kikaš, O. Horváth, I. Škorić, Tetrahedron Lett. 52 (2011) 6255.

${ }^{16}$ I. Kikaš, O. Horváth, I. Škorić, J. Mol. Struct. 1034 (2013) 62.

${ }^{17}$ A. Mrozek, J. Karolak-Wojciechowska, Polish J. Chem. 81 (2007) 721.

${ }^{18}$ D. C. Ericsson, L. E. Cuca, M. Sefkow, J. Nat. Prod. 72 (2009) 1245.

${ }^{19}$ D. Vidaković, I. Škorić, M. Horvat, Ž. Marinić, M. Šindler-Kulyk, Tetrahedron 64 (2008) 3928.

${ }^{20}$ M. Šindler-Kulyk, L. Špoljarić, Ž. Marinić, Heterocycles 29 (1989) 679.

${ }^{21}$ D. Cremer, J. A. Pople, J. Am. Chem. Soc. 97 (1975) 1354.

${ }^{22}$ L. J. Farrugia, J. Appl. Cryst. 30 (1997) 565.

${ }^{23}$ CrysAlis PRO, Oxford Diffraction Ltd., U.K., 2007.

${ }^{24}$ G. M. Sheldrick, Acta Crystallogr. A64 (2008) 112.

25 A. L. Spek, J. Appl. Cryst. 36 (2003) 7.

${ }^{26}$ C. F. Macrae, P. R. Edgington, P- McCabe, E. Pidcock, G. P. Shields, R. Taylor, M. Towler, J. ven de Streek, J. Appl. Cryst. 39 (2006) 453.

${ }^{27}$ R. Zhang, J. H. Horner, M. Newcomb, J. Am. Chem. Soc. 127 (2005) 6573.

${ }^{28}$ M. Newcomb, R. Zang, Z. Pan, D. N. Harischandra, R. E. P. Chandrasena, J. H. Horner, E. Martinez, Catal. Today 117 (2006) 98.

${ }^{29}$ H. Hock, H. Kropf, Angew. Chemie 69 (1957) 313. 